\title{
Pelatihan Kader Kesehatan untuk Prevensi Penyebaran Penyakit HIV/AIDS pada Ibu Rumah Tangga di Batujajar Timur Bandung Barat
}

\author{
Healthcare Giver Training to Prevent HIV/AIDS in Housewives in Batujajar Timur Bandung
} Barat

Patricia Gita Naully $\mathbf{1}^{*}$
Perdina Nursidika ${ }^{1}$
Indria Astuti ${ }^{2}$
1Department of Medical
Laboratory Technology, Sekolah
Tinggi Ilmu Kesehatan Jenderal
Achmad Yani Cimahi, Cimahi,
West Java, Indonesia
2Department of Midwifery,
Sekolah Tinggi Ilmu Kesehatan
Jenderal Achmad Yani Cimahi,
Cimahi, West Java, Indonesia
*email:
patriciagitanaully@gmail.com
Keywords:
HIV/AIDS Kata
HIV/AIDS
Ibu Rumah Tangga
Pelatihan
Accepted: November 2019
Published: December 2019
Traing

\begin{abstract}
Abstrak
Peningkatan jumlah penderita HIV/AIDS dari kalangan ibu rumah tangga semakin meningkat tiap waktu. Pemberian edukasi terhadap wanita dalam hal hak kesehatan reproduksi dan melawan stigma terhadap orang dengan HIV/ AIDS (ODHA) merupakan kunci untuk pencegahan. Pengabdian kepada masyarakat ini bertujuan untuk memberi pelatihan kepada ibu rumah tangga dalam rangka prevensi penyebaran penyakit HIV/AIDS pada ibu rumah tangga. Metode pengabdian masyarakat dilakukan dengan cara pemberian materi dalam bentuk ceramah dan media pembelajaran. Peserta diberikan pretest dan post test untuk menilai efektivitas pelatihan. Hasil pengabdian masyarakat menunjukkan semua peserta dapat mengikuti pelatihan dan meningkat dalam hal segi pengetahuan. Semua peserta juga akan melakukan pelatihan serupa pada ibu-ibu rumah tangga lain. Kesimpulan Kegiatan pelatihan ibu rumah tangga untuk pencegahan penyebaran HIV/AIDS dapat meningkatkan pengetahuan terhadap penyakit. Untuk pengabdian selanjutnya diharapkan dilanjutkan dengan kader yang mengikuti pelatihan, dapat memberikan pelatihan kepada ibu rumah tangga lainnya.
\end{abstract}

\begin{abstract}
An increasing number of people living with HIV/AIDS among housewives is increasing every time. Providing education to women in terms of reproductive health rights and fighting stigma against people with HIV/AIDS (PLWHA) is the key to prevention. Community service aims to provide training to housewives in the context of prevention of the spread of HIV/AIDS in housewives. The method of community service is done by presenting material in the form of lectures and learning media. Participants are given a pretest and post-test to assess the effectiveness of the training. The results of community service show that all participants can take part in the training and improve in terms of knowledge. All participants will also conduct similar training on other housewives. Conclusion Housewife training activities to prevent the spread of $\mathrm{HIV} / \mathrm{AIDS}$ can increase understanding of the disease. Further service is expected to be continued with cadres participating in the training, who can provide training to other housewives.
\end{abstract}

(c) 2019 Patricia Gita Naully, Perdina Nursidika, Indria Astuti. Published by Institute for Research and Community Services Universitas Muhammadiyah Palangkaraya. This is Open Access article under the CC-BY-SA License (http://creativecommons.org/licenses/by-sa/4.0/). DOI: https://doi.org/10.33084/pengabdianmu.v5i1.974.

\section{PENDAHULUAN}

Kasus HIV/AIDS di Bandung Barat mengalami peningkatan setiap tahun. Menurut data Dinas Kesehatan Kabupaten Bandung Barat, pada tahun 2017 angka penderita HIV/AIDS meningkat cukup tajam dan menjadi salah satu yang tinggi di Jawa Barat. Hal ini diduga akibat fenomena pergaulan bebas ditengah masyarakatyang sudah bukan barang tabu lagi. Tempattempat prostitusi di daerah tersebut semakin banyak dan cenderung diabaikan oleh pemerintah daerah setempat. Ironisnya, dari sekitar 249 kasus HIV/AIDS yang tersebar di 16 kecamatan Kabupaten Bandung Barat 
sepanjang tahun 2011-2016, sebagian besar di antaranya berasal dari kalangan ekonomi menengah ke bawah. Sepanjang 2014 sampai 2016, kasus HIV/AIDS ditemukan lebih banyak bukan lagi pada kelompok Pekerja Seks Komersial (PSK) atau homoseksual melainkan pada ibu rumah tangga (Dinas Kesehatan Provinsi Jawa Barat, 2017).

Peningkatan terjadi pada tahun 2018, adanya kasus baru HIV. penderita AIDS didominasi laki-laki, yakni sebanyak $64 \%$ dan perempuan $36 \%$. Sebagian besar masih berusia produktif antara 25-49 tahun. Bahkan, ada juga balita yang tertular HIV dari ibunya, yakni sekitar $3 \%$. Saat ini pun, ada 7 anak yang tengah dalam terapi HIV/AIDS di RSUD Cililin dan RSHS Bandung. Dari segi pekerjaan, $27 \%$ penderita merupakan karyawan swasta, $23 \%$ ibu rumah tangga, dan $17 \%$ pengangguran. Jumlah penderita dari kalangan pekerja seks komersial hanya 3\% (Sari, 2018a).

Menurut Ketua Komisi Penanggulangan AIDS (KPA) Kabupaten Bandung Barat, Lili Kusmayantoro, jumlah kasus HIV/AIDS pada ibu rumah tangga yang sebenarnya kemungkinan lebih banyak (Mawardi, 2018). Ketua KPA tersebut juga menyatakan bahwa peningkatan jumlah angka penderita HIV/AIDS ini dipengaruhi beberapa faktor seperti rendahnya pengetahuan masyarakat mengenai HIV/AIDS dan kesadaran dari masyarakat yang positif mengidap HIV/AIDS untuk memeriksakan diri ke Puskesmas atau KPA (Junita \& Dewi, 2016). Pemerintah Kabupaten Bandung Barat mengakui lambatnya penanganan HIV/AIDS akibat lambatnya dana hibah (Sari, 2018b).

Forum Kesehatan Reproduksi Wanita menyatakan pemberian edukasi terhadap wanita dalam hal hak kesehatan reproduksi dan melawan stigma terhadap orang dengan HIV/AIDS (ODHA) merupakan kunci untuk pencegahan. Data kementerian kesehatan menunjukkan 14.721 dari 102.667 ODHA antara 1987 dan 2017 adalah ibu rumah tangga. Data ini menunjukkan lebih tinggi daripada pekerja sex dengan HIV/AIDS yang hanya 3.314 orang. Ibu rumah tangga mendapatkan risiko transmisi HIV dari suaminya akibat rendahnya pengetahuan mengenai kesehatan reproduksi (Ikatan Perempuan Positif Indonesia, 2019) Cara yang efektif untuk menekan angka kejadian penyakit salah satunya adalah pendidikan kesehatan. Pendidikan kesehatan merupakan suatu kegiatan yang terbukti dapat meningkatkan pengetahuan seseorang terhadap suatu penyakit (Naully \& Nursidika, 2019).

Pendidikan kesehatan efektif terhadap peningkatan pengetahuan dan sikap. Peningkatan pengetahuan terjadi setelah remaja di SMA Isen Palangkaraya mendapatkan pelatihan konseling tentang organ reproduksi (Sukriani \& Natalina, 2018). Penelitian Dewi (2010) menunjukkan pendidikan kesehatan sangat efektif untuk meningkatkan pengetahuan dan sikap, pada ibu-ibu penderita HIV/AIDS. Hasil penelitian menunjukkan pembinaan, supervisi, dan pelatihan secara kontinu berperan penting dalam upaya promotif dan preventif HIV/AIDS.

Pengetahuan ini penting bagi ibu rumah tangga karena mereka menjadi golongan yang berisiko, sehingga dengan adanya pelatihan ini dapat membantu dalam pencegahan HIV/AIDS. Selain HIV/AIDS, hal yang bisa dicegah adalah koinfeksi penyakit lain. HIV/AIDS selalu disertai penyakit berbahaya lain seperti hepatitis B (Naully, 2018; Naully \& Romlah, 2018). Penyakit infeksi mudah berubah status, dari tingkat pribadi menjadi tingkat komunitas (Nursidika et al., 2014). Berdasarkan hal tersebut, pengabdian kepada masyarakat ini bertujuan untuk memberi pelatihan kepada ibu rumah tangga dalam rangka prevensi penyebaran penyakit HIV/AIDS pada ibu rumah tangga. 


\section{METODOLOGI}

Kegiatan penyuluhan HIV/AIDS akan dilakukan dengan menggunakan metode ceramah yang dilengkapi dengan media berupa power point, leaflet dan metode tanya jawab. Materi penyuluhan akan diberikan oleh Dosen Stikes Jenderal Achmad Yani Cimahi yang ahli dalam bidang imunologi, toksikologi, dan kebidanan. Materi yang diberikan antara lain pengertian HIV/AIDS, gejala, cara penularan, cara pencegahan, kesehatan seksual dan reproduksi, jenisjenis pelayanan HIV/AIDS yang tersedia, dan pentingnya tes laboratorium HIV. Kegiatan penyuluhan ini diawali dengan sesi perkenalan dan pre test, kemudian dilanjutkan dengan penyampaian materi penyuluhan. Penyampaian materi terbagi menjadi 3 sesi. Pada setiap akhir sesi materi akan dilakukan sesi tanya jawab dan diskusi. Terakhir dilakukan post test dan penutupan kegiatan. Seluruh kegiatan penyuluhan ini akan dilakukan di Puskesmas.

Untuk mengetahui dampak dan tingkat keberhasilan kegiatan penyuluhan akan dilakukan evaluasi pelaksanaan yang terdiri dari:

1. Pelaksanaan pre test mengenai HIV/AIDS yang dilakukan sebelum kegiatan dilaksanakan untuk mengetahui seberapa besar pengetahuan kelompok ibu rumah tangga tentang HIV/ AIDS

2. Pelaksanaan post test, tanya jawab, dan diskusi yang dilakukan pada akhir kegiatan untuk mengukur tingkat pemahaman peserta kegiatan terhadap materi yang disampaikan

3. Membandingkan nilai pre test dan post test sehingga dapat terlihat tingkatkeberhasilan kegiatan yang dilakukan

4. Analisis data hasil tes baik pre test maupun post test mengenai HIV/AIDS dengan teknik analisis deskriptif
5. Pelaksanaan survei yang dilakukan sebulan setelah kegiatan untuk mengetahui implementasi penyuluhan yang dilakukan.

\section{HASIL DAN PEMBAHASAN}

Kegiatan pengabdian masyarakat diawali dengan penyuluhan kader untuk prevensi penyakit HIV/AIDS. Kegiatan ini diawali dengan pemberian pretest untuk mengetahui sejauh mana pemahaman ibu rumah tangga terhadap penyakit HIV/AIDS, penyebaran, pengobagatan, dan faktor risiko.

Pretest pengetahuan dasar ini berbentuk pernyataan sederhana dengan jawaban Ya/Tidak.

Jenis Pertanyaan tersebut adalah:

1. Apakah Anda mengetahui apa itu penyakit HIV/AIDS?

2. Apakah Anda mengetahui gejala penyakit HIV/AIDS?

3. Apakah Anda mengetahui pengobatan penyakit HIV/AIDS?

4. Apakah Anda mengetahui cara pencegahan penyakit HIV/AIDS?

5. Apakah Anda membutuhkan pelatihan mengenai penyakit lain?

Hasil pretest menunjukkan semua mengetahui apa itu penyakit HIV/AIDS, semua mengetahui penyakit tersebut adalah penyakit berbahaya, menular, dan mematikan, sebagaimana disajikan pada Gambar 1. Namun hanya 45 peserta dari 189 peserta yang mengetahui gejala penyakit HIV/AIDS. Hanya 10 peserta yang mengetahui pengobatan penyakit HIV/AIDS dan 5 orang yang mengetahui cara pencegahan penyakit tersebut. Meskipun belum dilaksanakan penyuluhan, semua peserta pelatihan menyarankan adanya penyuluhan untuk penyakit lain. 


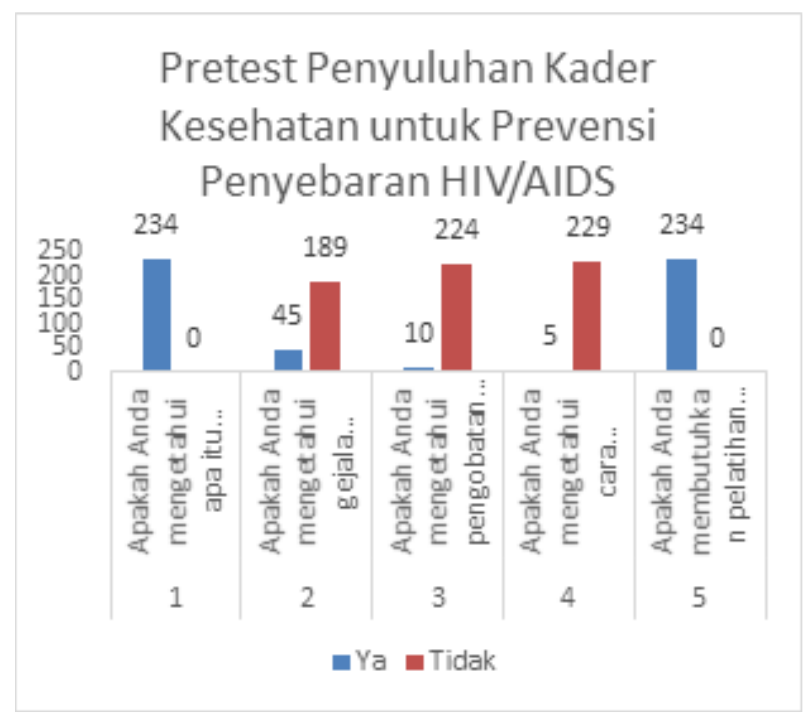

Gambar 1. Pretest pelatihan kader untuk prevensi penyebaran HIV / AIDS

Setelah pemberian pre test maka dilakukan penyuluhan dalam bentuk materi presentasi yang membahas tentang kasus HIV/AIDS di Bandung Barat, penyebaran HIV/AIDS di Bandung Barat salah satu yang paling mengejutkan adalah tingginya kasus pada ibu rumah tangga di Bandung Barat, penyebab HIV/AIDS, penyakit penyerta, gejala $\mathrm{HIV} / \mathrm{AIDS}$, penularan dan pencegahan, pengobatan berupa pengendalian penyakit HIV/AIDS sebagaimana disajikan pada Gambar 2.

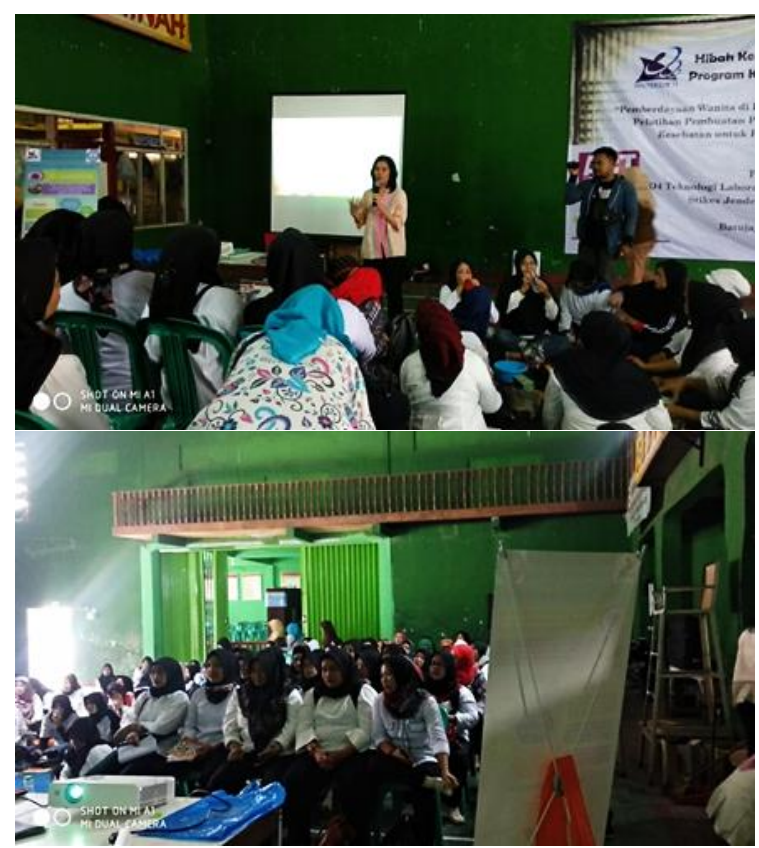

Gambar 2. Pemberian materi dalam bentuk presentasi (atas) yang disaksikan oleh peserta (Bawah)
Setelah pelaksanaan pemberian materi dan penyuluhan, peserta dievaluasi kembali menggunakan post test dengan pertanyaan yang sama dengan pre test. Hasil post test menyatakan setelah pelatihan, pengetahuan peserta mengenai bahaya HIV/AIDS, menjadi meningkat, sebagaimana disajikan pada Gambar 3.

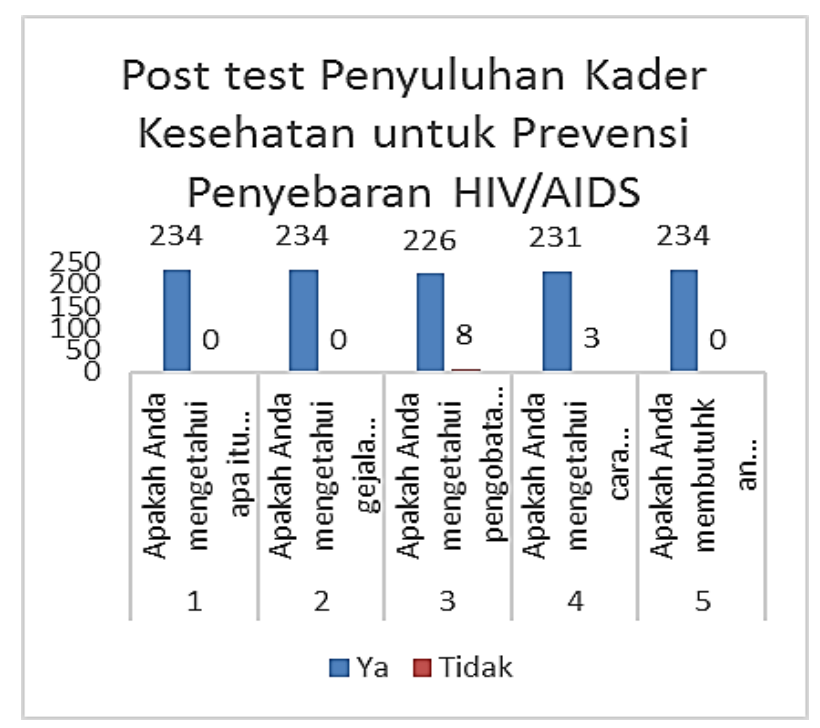

Gambar 3. Post test pelatihan kader untuk prevensi penyebaran HIV/ AIDS

Selain melalui pemberian materi presentasi, dilakukan pula penyuluhan melalui media promosi berupa $X$ banner yang berisi materi-materi yang sudah disampaikan. X-banner tersebut kemudian diserahkan kepada ibu kepala desa Batujajar Timur, agar disimpan dan dipajang di aula pertemuan ibu-ibu kader untuk selalu diingat dan diaplikasikan ilmunya kepada yang lain. Contoh media promosi disajikan pada Gambar 4.

Dari hasil pengabdian masyarakat didapatkan informasi bahwa ibu-ibu rumah tangga mendapatkan pengetahuan dan keterampilan dalam menyampaikan materi mengenai HIV/AIDS kepada ibu lain. Meskipun ibu rumah tangga bukan merupakan golongan dengan faktor risiko yang mudah terkena penyakit HIV/AIDS, namun Pendidikan kesehatan harus diberikan pada setiap golongan. Selain ibu rumah tangga, remaja pun menjadi sasaran WHO sebagai golongan yang perlu diberikan Pendidikan seks dan HIV (Ross et al., 2006). 


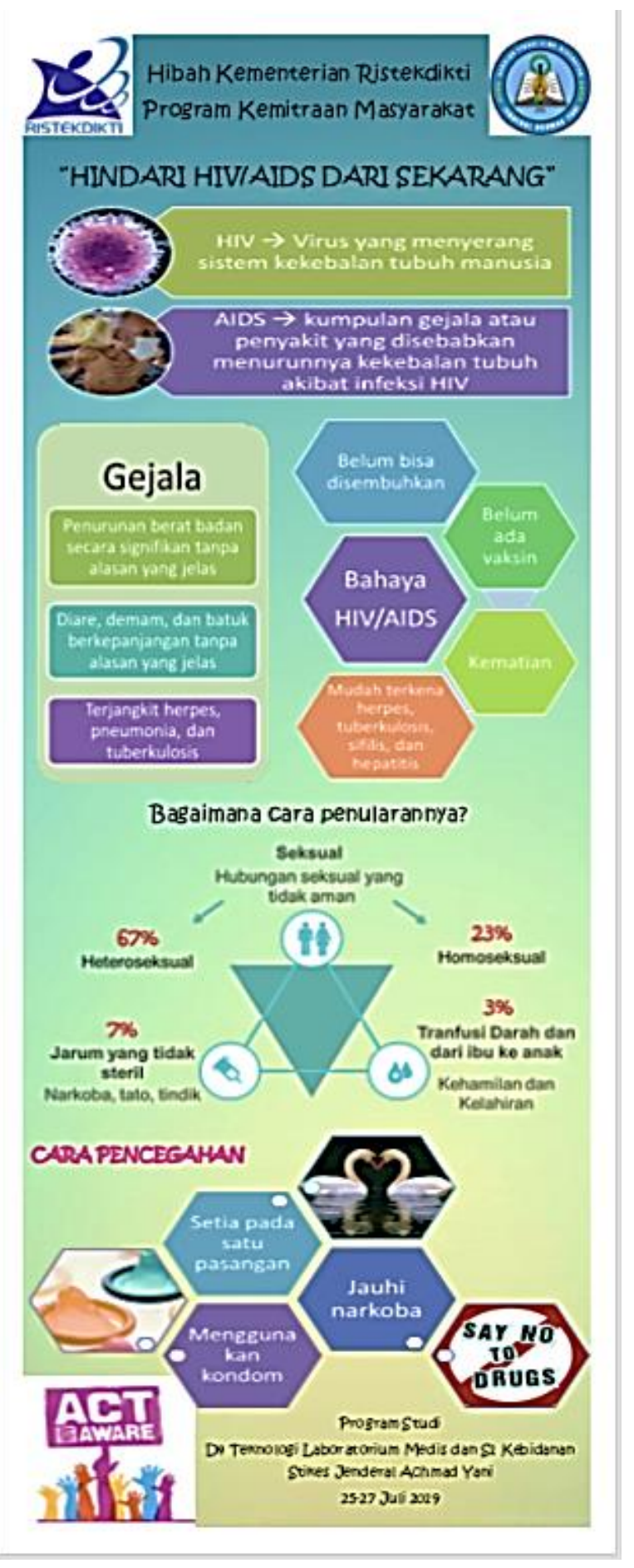

Gambar 4. Media penyuluhan

Program Pendidikan kesehatan dapat efektif dengan adanya pendekatan gender dan menggunakan pola kekuatan sosial (Haberland, 2015). Pelatihan ini memberdayakan wanita pengurus PKK sebagai kader kesehatan, sehingga dapat menjadi salah satu bagian penting dalam pencegahan penyeberan penyakit HIV/AIDS.

\section{KESIMPULAN}

Kegiatan pelatihan ibu rumah tangga untuk pencegahan penyebaran HIV/AIDS dapat meningkatkan pengetahuan terhadap penyakit. Untuk pengabdian selanjutnya diharapkan dilanjutkan dengan kader yang mengikuti pelatihan, dapat memberikan pelatihan kepada ibu rumah tangga lainnya.

\section{UCAPAN TERIMA KASIH}

Ucapan terimakasih sebesar-besarnya kami ucapkan kepada Ristekdikti, Stikes Jenderal Achmad Yani, kelurahan dan PKK Batujajar Timur Bandung Barat.

\section{REFERENSI}

Dewi, N.S. 2010. Pengaruh Pendidikan Kesehatan Terhadap Perubahan Pengetahuan Dan Sikap Dalam Pencegahan HIV/AIDS Pada Pekerja Seks Komersial. Nurse Media Journal of Nursing. 2(1):15-22. https://doi.org/10.14710/nmjn.v2i1.735

Dinas Kesehatan Provinsi Jawa Barat. 2017. Profil Kesehatan 2017 Dinas Kesehatan Provinsi Jawa Barat. Dinas Kesehatan Provinsi Jawa Barat.

Haberland, N.A. 2015. The Case for Addressing Gender and Power in Sexuality and HIV Education: A Comprehensive Review of Evaluation Studies. International Perspectives on Sexual and Reproductive Health. 41(5):31-51. https://doi.org/10.1363/SP00916

Ikatan Perempuan Positif Indonesia. 2019. Education key to preventing HIV/AIDS among housewives. The Jakarta Post. https://www.thejakartapost.com/news/201 9/04/24/education-key-preventing-hivaidsamong-housewives.html

Junita, S., Dewi, L. 2016. Pandangan Masyarakat Terhadap Penyakit HIV/AIDS Di Kecamatan Mentarang Kabupaten Malinau Kalimantan Utara. Journal of Holistic Nursing Science. 3(1):5976.

Mawardi, D. 2018. 14\% Pengidap HIV/AIDS di KBB Ibu Rumah Tangga. Galamedianews. 
https://www.galamedianews.com/?arsip=1 88553\&judul=14-pengidap-hivaids-di-kbbibu-rumah-tangga

Naully, P.G., Nursidika, P. 2019. Pendidikan Kesehatan: Upaya Mereduksi Angka Infeksi Menular Seksual pada Komunitas Homoseksual di Kota Bandung. Caradde: Jurnal Pengabdian Kepada Masyarakat. 2(1):53-59. https://doi.org/10.31960/caradde.v2i1.136

Naully, G.P. 2018. Koinfeksi Human Immunodeficiency Virus Dan Hepatitis B Virus Pada Orang Bertato Di Cimahi. Judika (Jurnal Nusantara Medika). 2(2):1-9. https://doi.org/10.29407/judika.v2i1.12176

Naully, P.G., Romlah, S. 2018. Prevalensi HIV dan HBV pada Kalangan Remaja. Jurnal Kesehatan. 9(2):280-288.

http://dx.doi.org/10.26630/jk.v9i2.908

Nursidika, P., Saptarini, O., Rafiqua, N. 2014. Aktivitas Antimikrob Fraksi Ekstrak Etanol Buah Pinang (Areca catechu L) pada Bakteri Methicillin Resistant Staphylococcus aureus. Majalah Kedokteran Bandung (MKB). 46(2):94 99.

http://dx.doi.org/10.15395/mkb.v46n2.280

Ross, D.A., Dick, B., Ferguson, J. 2006. Preventing HIV/AIDS in Young People: A Systematic Review of The Evidence from Developing Countries. Geneva: World Health Organization Press.

Sari, C.W. 2018a. 5 Warga Meninggal Akibat HIV AIDS, Ini yang Dilakukan Dinkes Bandung Barat. In Pikiran Rakyat. https://www.pikiranrakyat.com/bandung-raya/pr-01301830/25warga-meninggal-akibat-hiv-aids-ini-yangdilakukan-dinkes-bandung-barat

Sari, C.W. 2018b. Penanggulangan HIV di Bandung Barat Terganggu Macetnya Dana Hibah. Pikiran Rakyat. https://www.pikiranrakyat.com/bandung-raya/pr01300991/penanggulangan-hiv-di-bandungbarat-terganggu-macetnya-dana-hibah429842

Sukriani, W., Natalina, R. 2018. Pengenalan Organ Reproduksi pada Remaja Putri di SMA Isen Mulang Kota Palangka Raya. Pengabdianmu: Jurnal Ilmiah Pengabdian kepada Masyarakat. 3(2):160-166. https://doi.org/10.33084/pengabdianmu.v3i 2.384 